\title{
Physicality in Australian Patent LAW
}

\section{BEN MCENIERY*}

It is generally understood that the patent system exists to encourage the conception and disclosure of new and useful inventions embodied in machines and other physical devices, along with new methods that physically transform matter from one state to another. What is not well understood is whether, and to what extent, the patent system is to encourage and protect the conception and disclosure of inventions that are nonphysical methods - namely those that do not result in a physical transformation of matter. This issue was considered in Grant $\mathrm{v}$ Commissioner of Patents. In that case the Full Court of the Federal Court of Australia held that an invention must involve a physical effect or transformation to be patentable subject matter. In doing so, it introduced a physicality requirement into Australian law. What this article seeks to establish is whether the court's decision is consistent with the case law on point. It does so by examining the key common law cases that followed the High Court's watershed decision in National Research Development Corporation $\mathrm{v}$ Commissioner of Patents, the undisputed authoritative statement of principle in regard to the patentable subject matter standard in Australia. This is done with a view to determining whether there is anything in those cases that supports the view that the Australian patentable subject matter test contains a physicality requirement.

\section{INTRODUCTION}

Conventional thinking in Australia and other places has been that patents are the domain of engineering, applied science and industrial manufacturing. As a consequence, it is commonly thought that patent law's influence extends only as far as the protection of inventions embodied in new and useful machines

* BA, LLB (Hons) (UQ), LLM (QUT), PhD (QUT), Senior Lecturer, Faculty of Law, Queensland University of Technology, Barrister-at-Law, Level 17, 95 North Quay, Brisbane. I thank Professor Brian Fitzgerald and Professor Anne Fitzgerald for their helpful suggestions. All errors are naturally my own. 
and other physical devices, and new methods that physically transform matter from one state into another. This traditional conception of the role of the patent system is something that is arguably inherited from mid-nineteenth century British law, ${ }^{1}$ and is a corollary of a belief that technology is something necessarily tied to machines, physical devices and substances, and physically-transformative methods. ${ }^{2}$ Although these traditional expectations still exist in the $21^{\text {st }}$ century, it is doubtful that the law is actually constrained in this way. In other words, it is yet to be adequately resolved whether Australian patent law contains a physicality requirement.

While it is clear that the presence of a machine or other physical artefact or a physically transformative method is a strong indicator of patentable subject matter, what is not clear is why non-physical methods, being those that do not involve a machine or other physical device and those that do not involve a physical transformation of matter, ought to be denied patent eligibility. Tying patent eligibility to the physical binds the patent system to industrial technologies and leaves it unable to respond flexibly to new technologies as they arise. ${ }^{3}$

Addressing the issue of whether patent law contains a physicality requirement demands an understanding of the nature of the patent law bargain. That bargain is that exclusive rights to exploit an invention are granted only in exchange for a full public disclosure of the invention and its workings. Thus, the nature of the patent law bargain involves a careful balancing of the public's right to make use of, and make improvements to, new information

${ }^{1}$ The King $v$ Wheeler (1819) 2 B \& Ald 345, 349; 106 ER 392, 394-95; Bristol-Myers Co $v$ Beecham Group Ltd [1974] AC 646, 677-8, in which Lord Diplock observed of the 'archaic language' of the Statute of Monopolies that it: 'would appear to contemplate as the principal subject of monopolies new artefacts which had not been made before in England, and in some of the very earliest authorities this view appears to have found favour with the courts; but it did not survive and it has been long established that under the Statute of Monopolies patents could also be granted for new processes for making artefacts which were not themselves new'. See also Lionel Bently and Brad Sherman, Intellectual Property Law (Oxford University Press, 2001) 310 ('the image of the invention as the human intervention into nature that brings about a resulting physical change that underpins much contemporary jurisprudence, was well entrenched in British law by the mid-nineteenth century.').

${ }^{2}$ Ben McEniery, 'The Patentability of Non-Physical Inventions: Lessons from the United States' (2009) 35(2) Monash University Law Review 376, 377-8.

${ }^{3}$ For authority as to the proposition that there is a need for the patent system to respond flexibility to accommodate to new technologies as they arise, see National Research Development Corporation v Commissioner of Patents (1959) 102 CLR 252 and American Cyanamid Company (Dann's) Patent (Dann's Patent) [1971] RPC 425, 451-2 (Lord Diplock). 
and ideas, and the private right to protection from free riders. ${ }^{4}$ The question to ask in this regard is whether allowing patents to be granted for non-physical inventions violates fundamental notions as to what a patent is and what ends patent law is supposed to achieve.

\section{The Grant DeCISION - Finding A Physicality REQUIREMENT}

This question was considered by the Full Federal Court in Grant $v$ Commissioner of Patents ${ }^{5}$ ('Grant'). There, the Court held that, to be patentable subject matter, an invention must result in the production or alteration of a physical object or produce a physically observable effect. ${ }^{6}$

The patent application considered in Grant was without doubt an unconventional use of the patent system. It sought to reserve to one individual the right to apply certain aspects of the law in a particular way to achieve a useful result. It was just one of many attempts by innovators in professional services firms to seek the same rewards and advantages offered by the patent system that have traditionally been awarded to engineers and industrialists. The claimed invention in Grant was a business method aimed at protecting an asset from the claims of creditors. However, Mr Grant's claimed invention was not merely a business method, but was a business method devoid of any physical constraints. The claims listed the steps of: creating a trust; a person making a gift of money to the trust; the trustee lending a sum of money to the person, and, finally, the trustee securing the loan by taking a charge over the asset. The purpose of the method was to establish a charge over the asset in favour of the trustee that took priority over the claims of other creditors. ${ }^{7}$

\footnotetext{
${ }^{4}$ Suzanne Scotchmer, 'Standing on the Shoulders of Giants: Cumulative Research and the Patent Law' (1991) 5(1) Journal of Economic Perspectives 29, 29-34; Mark A Lemley, 'The Economics of Improvement in Intellectual Property Law' (1997) 75 Texas Law Review 989, 997; Robert P Merges and Richard R Nelson, 'On the Complex Economics of Patent Scope' (1990) 90 Columbia Law Review 839. See also Alvin Edward Moore, 'Edison and the Phonograph' (1932) 14 Journal of the Patent Office Society 39, 39.

5 [2006] FCAFC 120 (18 July 2006) (Heerey, Kiefel and Bennett JJ).

${ }^{6}$ Ibid [30], [32], [47]. For a concise summary of the Full Court's decision, see Brian Fitzgerald et al, Internet and E-commerce Law: Business and Policy (Thomson Reuters, 2011) 504-6.

${ }^{7}$ Australian Innovation Patent No 2003100074 ('Asset Protection Method') (filed February 7, 2003).
} 
On appeal, the Full Court ruled the patent invalid, upholding the decisions of the Deputy Commissioner of Patents, ${ }^{8}$ and a single judge of the Federal Court. ${ }^{9}$ In doing so, the Full Court concluded that any method that does not produce a physical result is merely 'intellectual information', which has never been patentable. ${ }^{10}$ The Court did not hold the patent invalid because it described a business method. Although the Court accepted that business methods are not excluded from patent eligibility as a category subject matter, it found that a business method removed from any physical apparatus or other physical embodiment is not patentable subject matter. ${ }^{11}$

In its reasons, the Full Court asked whether the alleged invention before it was a proper subject of letters patent according to the principles which have developed over time to guide the application of section 6 of the Statute of Monopolies. The Court examined a number of cases and observed that the patentability of an invention that does not produce a physical effect or cause a physical transformation of matter has never been upheld. ${ }^{12}$ From this observation, the Court inferred that non-physical methods are categorically excluded from patent eligibility. ${ }^{13}$

The Grant decision has been criticised in the academic literature on the grounds that it is fundamentally inconsistent with the principles set out in the

\footnotetext{
${ }^{8}$ Stephen John Grant (2004) 62 IPR 143.

${ }^{9}$ The matter was originally heard before a single judge of the Federal Court of Australia: Grant $v$ Commissioner of Patents [2005] FCA 1100 (12 August 2005) (Branson J).

${ }^{10}$ Grant $v$ Commissioner of Patents [2006] FCAFC 120 (18 July 2006) [14]-[23].

${ }^{11}$ Ibid [47].

12 The Court considered: Burroughs Corporation (Perkins') Application [1974] RPC 147; Commissioner of Patents $v$ Lee (1913) 16 CLR 138; Commissioner of Patents v Microcell Ltd (1959) 102 CLR 232; International Business Machines Corporation's Application [1980] FSR 564; International Business Machines Corporation v Commissioner of Patents (1991) 33 FCR 218; Neilson v Minister of Public Works (NSW) (1914) 18 CLR 423; Re Brown (1899) 5 ALR 81; Re Cooper's Application for a Patent (1901) 19 RPC 53; Re ESP's Application (1944) 62 RPC 87; Re Fishburn's Application (1938) 57 RPC 245; Re GEC's Application (1942) 60 RPC 1; Re Johnson's Application for a Patent (1901) 19 RPC 56; Re Lenard's Application (1954) 71 RPC 190; Re W's Application (1914) 31 RPC 141; Rogers $v$ Commissioner of Patents (1910) 10 CLR 701. The Court noted that in NRDC, an artificial effect was physically created on the land, and that in each of Welcome Real-Time SA v Catuity Inc, CCOM v Jiejing and in the United States decisions of State Street Bank \& Trust Co v Signature Financial Group and AT\&T Corp v Excel Communications, Inc, there was a component physically affected or a change in state or information in a part of a device or machine.

${ }^{13}$ Ben McEniery, 'Patents for Intangible Inventions in Australia after Grant $v$ Commissioner of Patents (Part 2)' (2007) 13(3) Computer and Telecommunications Law Review 100, 102.
} 
High Court's landmark decision in National Research Development Corporation $v$ Commissioner of Patents ${ }^{14}$ ('NRDC'). It has been argued that, in $N R D C$, the High Court explained that the patentable subject matter inquiry is a broad test that recognises all new and useful innovation as patent eligible, irrespective of whether it involves a physical embodiment or a transformation of physical matter. ${ }^{15}$

That Grant is inconsistent with the principles set out in NRDC is confirmed, albeit by way of obiter, in the High Court's 2002 decision in Grain Pool of WA v Commonwealth. ${ }^{16}$ There the Court said:

At the time of the enactment of the Constitution, there was still awaiting for final decision the question whether it was enough that a process produced a useful result or whether it was necessary that some physical thing either be brought into existence or be so affected such as better to serve the purposes of mankind. The point was not settled until the celebrated judgment of Dixon CJ, Kitto and Windeyer JJ in National Research Development Corporation $v$ Commissioner of Patents. Their Honours held that the requirement of a 'vendible product' for a valid process claim meant no more than that the end produced be of utility in practical affairs. ${ }^{17}$

While the academic literature on point is valuable, it does not systematically address whether the Federal Court's finding in Grant is consistent with the decisions in the important cases that followed and interpreted the High Court's statements of principle in $N R D C$. This article aims to fill that gap by examining whether there is anything in that case law which supports the finding in Grant that Australian patent law contains a physicality requirement, or supports a patent eligibility standard free of physical constraints.

An analysis of the post- $N R D C$, pre-Grant case law is desirable because those cases contain the most recent judicial analysis of the patent eligibility standard that Australian law has to draw from when assessing the patentability of new

\footnotetext{
${ }^{14}$ (1959) 102 CLR 252.

${ }^{15}$ Ben McEniery, 'Patents for Intangible Inventions in Australia after Grant v Commissioner of Patents (Part 1)' (2007) 13(2) Computer and Telecommunications Law Review 70; McEniery, 'Patents for Intangible Inventions in Australia (Part 2)', above n 13. See also: Ann L Monotti, 'The Scope of 'Manner of Manufacture' Under the Patents Act 1990 (Cth) after Grant $v$ Commissioner of Patents' (2006) 34(3) Federal Law Review 461; McEniery, 'The Patentability of Non-Physical Inventions: Lessons From the United States', above n 2; Charles Lawson, 'Grant $v$ Commissioner of Patents and Patenting Knowledge Inventions' (2008) 15 Journal of Law and Medicine 626.

${ }^{16}$ (2000) 202 CLR 479.

${ }^{17}$ Ibid 502.
} 
technologies. Assessing these cases is necessary because they are cases in which non-industrial subject matter, such as computer software and business methods, is considered in light of the approach to subject matter eligibility prescribed by the Statute of Monopolies. Included in this discussion is a selection of the pre-1977 United Kingdom cases, which are considered to be of persuasive influence in Australia. ${ }^{18}$ What is sought from this analysis is language in the jurisprudence to indicate whether judges over time have been open to the possibility that patent eligible subject matter might exist in an invention where the inventive concept is free of any physical embodiment.

\section{Physicality and Patent Law Theory}

The theoretical underpinning or justification for the patent system is that it exists to encourage innovation by providing incentives to invent and invest in innovation and to disclose the workings of new technologies to the public. Possibly the best enunciation of the purpose of patent law, and one that is consistent with the aims of the patent system worldwide, comes from the United States Supreme Court's decision in Aronson v Quick Point Pencil Co: ${ }^{19}$

First, patent law seeks to foster and reward invention; second, it promotes disclosure of inventions to stimulate further innovation and to permit the public to practice the invention once the patent expires; third, the stringent requirements for patent protection seek to assure that ideas in the public domain remain there for the free use of the public. ${ }^{20}$

It is the potential economic rewards to be reaped during the patent term that induce the time, effort, expenditure and other resources needed for innovation to occur. This can be seen in the patent custom of the Venetian Republic, ${ }^{21}$

\footnotetext{
${ }^{18}$ The reason for tracing United Kingdom law only to 1977 is that 1977 is the year the United Kingdom abandoned its Statute of Monopolies-based regime for a new patent system modelled on the Convention on the Grant of European Patents, opened for signature 5 October 1973, 13 ILM 268 (entered into force 7 October 1977) ('European Patent Convention'). See Patents Act 1977 (UK) c 37.

${ }^{19} 440$ US 257 (1979).

${ }^{20}$ Ibid 262.

${ }^{21}$ Giulio Mandich, 'Venetian Patents (1450-1550)' (1948) 30 Journal of the Patent Office Society 166 (F D Prager trans); Giulio Mandich, 'Venetian Origins of Inventor's Rights' (1960) 42 Journal of the Patent Office Society 378 (F D Prager trans); Edward C Walterscheid, 'The Early Evolution of the United States Patent Law: Antecedents (Part 1)' (1994) 76 Journal of the Patent \& Trademark Office Society 697, 709-710; Frank D Prager,
} 
and the earliest English custom of granting monopolies. ${ }^{22}$ The rationale is equally evident in today's modern patent system ${ }^{23}$ and is regarded as the justification for the existence of patent law in Australia today. ${ }^{24}$ Thus, patent law does not recognise the existence of natural rights that vest automatically in an inventor, but provides an economic incentive to encourage inventors to create inventions for the benefit of the public. ${ }^{25}$

Innovation, the creation and application of new ideas, is a key factor in achieving economic growth and prosperity. ${ }^{26}$ Innovation is considered to be an essential ingredient for economic growth and is a key factor that contributes to prosperity and raises standards of living. ${ }^{27}$ Prosperity, or

\footnotetext{
'A History of Intellectual Property from 1545 to 1787 ' (1944) 26(11) Journal of the Patent Office Society 711, 715, 750.
}

${ }^{22}$ Edward Coke, Institutes of the Laws of England (1628-1644) vol 3, 184 ('The reason wherefore such a privilege is good in law is because the inventor bringeth to and for the common wealth a new manufacture by his invention, costs and charges, and therefore it is reason, that he should have a privilege for his reward (and the encouragement of others in the like) for a convenient time.'); Statute of Monopolies 21 Jam 1, Ch 3 (1623) (Eng).

${ }^{23}$ Fritz Machlup, 'An Economic Review of the Patent System' (Study No 15, Subcommittee on Patents, Trademarks and Copyrights, Committee on the Judiciary, $85^{\text {th }}$ Cong, 2d Sess, 1958) 36-8; Roberto Mazzoleni and Richard R Nelson, 'The Benefits and Costs of Strong Patent Protection: A Contribution to the Current Debate' (1998) 27(3) Research Policy 273; Lionel Bently and Brad Sherman, Intellectual Property Law (Oxford University Press, $3^{\text {rd }}$ ed, 2001) 315.

${ }^{24}$ CCOM v Jiejing (1994) 122 ALR 417, 433; Advanced Building Systems Pty Ltd v Ramset Fasteners (Aust) Pty Ltd (1998) 194 CLR 171, 195 (Kirby J); Welcome Real-Time SA v Catuity Inc [2001] FCA 445 [129] (Heerey J) ('the law has to strike a balance between, on the one hand, the encouragement of true innovation by the grant of monopoly and, on the other, freedom of competition.'); Ronald Sackville, 'Monopoly Versus Freedom of Ideas: The Expansion of Intellectual Property' (2005) 16 Australian Intellectual Property Journal 65, 6566. This is the case despite the Patents Act containing no statement as to its purpose. In this regard, Australia is not alone in failing to include any clear statement of objectives in its patent statute.

${ }^{25}$ Machlup, above n 23, 29-30; Paul E Schaafsma, 'An Economic Overview of Patents' (1997) 79 Journal of the Patent \& Trademark Office Society 241, 243.

${ }^{26}$ Organisation for Economic Co-operation and Development, 'The Knowledge-Based Economy' (Report, 1996) 3; Organisation for Economic Co-operation and Development, 'A New Economy? The Changing Role of Innovation and Information Technology in Growth' (Study, 2000); Organisation for Economic Co-operation and Development, 'The New Economy: Beyond the Hype' (Final Report on the OECD Growth Project, 2001).

${ }^{27}$ United States Federal Trade Commission, 'To Promote Innovation: The Proper Balance of Competition and Patent Law and Policy' (Report, 28 October 2003) 1, citing Federal Reserve Board Vice Chairman Roger W Ferguson Jr, 'Patent Policy in a Broader Context' (Speech delivered at the 2003 Financial Markets Conference of the Federal Reserve Bank of Atlanta, Sea Island, Georgia, 5 April 2003): 'innovation benefits consumers through the development of new and improved goods, services, and processes. An economy's capacity for invention 
success in material terms, is achieved through maximising innovative output and the creation of new technologies. ${ }^{28}$

Creating useful ideas takes time, effort, expenditure and other resources. While the costs of producing the information that describes an invention may be high, once conceived, that information is capable of being copied at negligible cost without re-incurring the initial costs of its conception. Patent protection allows the patentee to charge an uncompetitive price in an absence of competition in order to appropriate a larger share of the social benefits of an invention than he or she might otherwise receive. In the absence of a patent monopoly, free riders who imitate and reverse engineer can lawfully earn profits by selling competing products without having to recoup the sunken costs of creating the invention. In doing so, they profit from the inventor's ingenuity and diminish his or her market share. Without the patent system, too few new ideas would be created and new inventions would be under produced or not produced at all. ${ }^{29}$

Since innovation is nothing more than the creation of new knowledge and ideas and is not contingent on the creation of new machines, physical devices and transformative methods, from a theoretical perspective it makes little sense to limit the scope of patentable subject matter to new technologies that are bound by physical constraints.

\section{The Patentable Subject Matter Test}

There are two types of patents in Australia: standard patents and innovation patents. Standard patents confer monopoly protection for inventions for a

\footnotetext{
and innovation helps drive its economic growth and the degree to which standards of living increase.'

${ }^{28}$ Fritz Machlup, The Production and Distribution of Knowledge in the United States (Princeton University Press, 1962); Carl Shapiro and Hal R Varian, Information Rules: A Strategic Guide to the Network Economy (Harvard Business Press, 1999). In fact, economists trace 30 to 40 per cent of all gains in productivity and growth in the United States over the course of the 20th century to economic innovation in its various forms: Robert J Shapiro and Nam D Pham, Economic Effects of Intellectual Property: Intensive Manufacturing in the United States (July 2007) <http://www.sonecon.com/docs/studies/0807 thevalueofip.pdf $>$.

${ }^{29}$ Robert P Merges, Peter S Menell and Mark A Lemley, Intellectual Property in the New Technological Age (Aspen Law and Business, 3rd ed, 2003), 10-18; Peter S Menell, 'An Analysis of the Scope of Copyright Protection for Application Programs' (1989) 41 Stanford Law Review 1045, 1059-1066; Mark A Lemley, 'Ex Ante versus Ex Post Justifications for Intellectual Property' (2004) 71 University of Chicago Law Review 129, 129.
} 
maximum term of 20 years. ${ }^{30}$ Innovation patents, which require a significantly lesser degree of inventiveness, are awarded for a maximum term of 8 years. ${ }^{31}$ This limited period of monopoly protection is given to the inventor, or his or her assignee, in exchange for revealing to the public the workings of the technology described in the invention.

The statutory basis of the Australian patentable subject matter test lies in section 18(1) of the Patents Act 1990 (Cth). That provision states that an invention, to be a patentable invention, must lie within the bounds of patentable subject matter (the 'manner of manufacture' test), be novel, involve an inventive step, be practically useful, and not have been used in secret so as to extend the period of monopoly protection beyond that provided by the statute.

Section 18(1) provides that 'an invention is a patentable invention', where a standard patent is concerned:

if the invention, so far as claimed in any claim:

(a) is a manner of manufacture within the meaning of section 6 of the Statute of Monopolies; and

(b) when compared with the prior art base as it existed before the priority date of that claim:

(i) is novel; and

(ii) involves an inventive step; and

(c) is useful; and

(d) was not secretly used in the patent area before the priority date of that claim by, or on behalf of, or with the authority of, the patentee or nominated person or the patentee's or nominated person's predecessor in title to the invention.

\footnotetext{
${ }^{30}$ Patents Act 1990 (Cth) s 67.

${ }^{31}$ Ibid s 68. The innovation patent is a second-tier patent introduced into Australian law by the Patents Amendment (Innovation Patents) Act 2000 (Cth).
} 
The test for an innovation patent is similar, the main difference being that an innovative step, rather than an inventive step, is required. ${ }^{32}$

The focus of this article is the 'manner of manufacture' requirement, which determines the scope of patentable subject matter. The 'manner of manufacture' requirement stems from section 6 of the Statute of Monopolies, ${ }^{33}$ a 400 -year-old English statute that is the basis of modern patent law and practice. ${ }^{34}$

The object of the Statute of Monopolies was the curtailment of the Crown practice of granting monopolies to court favourites in goods or businesses which had long before been enjoyed by the public, a practice considered to be contrary to the common law. ${ }^{35}$ While the objective of the Statute of Monopolies was to declare grants of monopolies void, ${ }^{36}$ it recognised nonetheless that monopolies which pertained to inventions and were limited in duration might serve the public interest by providing an incentive to invent and to bring new technologies to the realm.

32 Patents Act 1990 (Cth) s 18(1A). Section 18(3) and (4) further provides that certain inventions are not patentable inventions for the purposes of an innovation patent. These include 'patent, plants and animals, and the biological processes for the generation of plants and animals' unless 'the invention is a microbiological process or a product of such a process'.

${ }^{33} 21$ Jam 1, ch 3 (1623) (Eng). The Statute of Monopolies is the short title of the Act. The long title is 'An Act Concerning Monopolies and Dispensations with Penal Laws and the Forfeiture Thereof'.

${ }^{34}$ Ramon A Klitzke, 'Historical Background of the English Patent Law' (1959) 41 Journal of the Patent Office Society 615, 615 ('The basic truths found by the English 400 years ago are still valid today and should continue to influence us in the interpretation and application of our law, even though it has become greatly refined and perfected.').

35 Jacob I Corré, 'The Argument, Decision and Reports of Darcy v. Allen' (1996) 45 Emory Law Journal 1261, 1261. The fame of Darcy v Allen is largely due to the reports of Sir Edward Coke: (1603) 11 Coke Rep 84b, 77 Eng Rep 1260. Coke appeared as AttorneyGeneral before the Kings Bench in Darcy $v$ Allen, was one of the reporters of the case and was involved in drafting of the Statute of Monopolies. Two other reports exist: (1603) 72 Eng Rep 830 (Moore 671); (1603) Noy 173, 74 Eng Rep 1131. The case has also been referred to as 'Darcy $v$ Allin' or 'Darcy $v$ Allein'.

${ }^{36}$ Section 1 of the Statute of Monopolies provides that the central objective of the statute is to encourage free trade and competition by rendering void all monopolies, including those granted under the authority of letters patent. Section 1 provides: 'All monopolies and all commissions, grants, licenses, charters and letter patent theretofore made or granted or heretofore to be made or granted to any person or persons, bodies politic or corporate whatsoever, of or for the sole buying, selling, making or using of anything within this realm ... are utterly void and of no effect.' 
How the reference to section 6 of the Statute of Monopolies in modern Australian patent statutes is to be interpreted was explained by the High Court of Australia in NRDC. ${ }^{37}$ The Court held that the relevant question to be asked when determining whether an invention is patentable subject matter is:

Is this a proper subject of letters patent according to the principles which have been developed for the application of s 6 of the Statute of Monopolies? ${ }^{38}$

What the Court meant is that the scope of patentable subject matter is to be determined by reference to what has been deemed to be patentable by the courts over time.

The NRDC court embraced the view that 'manner of manufacture' is a broad, flexible and dynamic concept, the meaning of which has evolved, and will continue to evolve, over time. ${ }^{39}$ It said that the principles are to be applied flexibly, as technological advancement is 'excitingly unpredictable' and that it is not appropriate to attempt to reduce the patentable subject matter test to 'an exact verbal formula'. ${ }^{40}$

The purpose of s 6 , it must be remembered, was to allow the use of the prerogative to encourage national development in a field which already, in 1623 , was seen to be excitingly unpredictable. To attempt to place upon the idea the fetters of an exact verbal formula could never have been sound. It would be unsound to the point of folly to attempt to do so now, when science has made such advances that the concrete applications of the notion which were familiar in 1623 can be seen to provide only the more obvious, not to say the more primitive, illustrations of the broad sweep of the concept. ${ }^{41}$

Rather, the Court viewed the expression 'manner of manufacture' as being a general title to be interpreted in accordance with the purpose of the Statute of Monopolies and in line with common law principles established for the application of that purpose.

\footnotetext{
${ }^{37}$ In NRDC, the Court considered the operation of the Statute of Monopolies in relation to the legislation then in force (Patents Act 1952 (Cth)).

${ }^{38}$ NRDC (1959) 102 CLR 252, 269.

${ }^{39}$ Ibid 270.

${ }^{40}$ Ibid 271 (cited and followed in Grant [2006] FCAFC 120 (18 July 2006) [7]-[8]).

${ }^{41}$ Ibid.
} 
The inquiry which the definition demands is an inquiry into the scope of the permissible subject matter of letters patent and grants of privilege protected by the section. It is an inquiry not into the meaning of a word so much as into the breadth of the concept which the law has developed by its consideration of the text and purpose of the Statute of Monopolies. One may remark that although the Statute spoke of the inventor it nowhere spoke of the invention; all that is nowadays understood by the latter word as used in patent law it comprehended in 'new manufactures'. The word 'manufacture' finds a place in the present Act, not as a word intended to reduce a question of patentability to a question of verbal interpretation, but simply as the general title found in the Statute of Monopolies for the whole category under which all grants of patents which may be made in accordance with the developed principles of patent law are to be subsumed. ${ }^{42}$

The High Court held that, to be patentable, an invention must be an artificially created state of affairs of economic significance, meaning that its value to the country must be in the field of economic endeavour, and that it must have 'an industrial or commercial or trading character'. ${ }^{43}$ Further, it said the invention must offer some advantage that is material in the sense that it must be part of the 'useful arts' rather than the 'fine arts'. 44

The point is that a process ... must be one that offers some advantage which is material, in the sense that the process belongs to a useful art as distinct from a fine art. ${ }^{45}$

The Court identified several categories of excluded matter to aid in distinguishing between patentable and non-patentable subject matter. It made clear that patents protect new inventions and not discoveries, be they discoveries of the laws of nature, natural phenomena, or abstract ideas. ${ }^{46}$ In

\footnotetext{
${ }^{42}$ Ibid 269.

${ }^{43}$ Ibid 275-7.

${ }^{44}$ On attempts to patent subject matter within the fine arts see: Ben McEniery, "'Storyline Patents": Are Plots Patentable?' (2009) 33(1) Melbourne University Law Review 291.

${ }^{45}$ NRDC (1959) 102 CLR 252, 275 citing Re Virginia-Carolina Chemical Corporation's Application (1958) RPC 35, 36.

${ }^{46}$ Ibid 262-4. It is argued that in this respect, the Australian law is identical to the position in the United States. Examples of laws of nature include Sir Isaac Newton's observations on the law of gravity and Albert Einstein's general theory of relativity, while abstract ideas include novel and useful mathematical formulae: Diamond v Chakrabarty, 447 US 303, 309 (1980); Diamond v Diehr, 450 US 175, 185 (1981). A recent Australian example is Milton Edgar Anderson [2008] APO 19 (11 August 2008). There the Deputy Commissioner of Patents upheld the view that an alleged invention that relates to a mere scientific theory or discovery of the laws of nature, but is lacking a specific practical and useful application is not a 'manner of manufacture'. The application in question relates to 'the new science of subtronics' and 'a
} 
regard to the distinction between unpatentable discoveries and patentable inventions the Court said that:

There may indeed be a discovery without invention - either because the discovery is of some piece of abstract information without any suggestion of a practical application of it to a useful end, or because its application lies outside the realm of 'manufacture'. ${ }^{47}$

What the Court did not find was that non-physical inventions are a category of excluded matter. Rather, the Court left that question unresolved.

But a question which appears still to await final decision is whether it is enough that a process produces a useful result or whether it is necessary that some physical thing is either brought into existence or so affected as the better to serve man's purposes. ${ }^{48}$

The author has argued previously that the NRDC court's broad and expansive statement of principle precludes any suggestion that the patentable subject matter test might involve a physicality requirement ${ }^{49}$ and that, accordingly, the Federal Court's finding in Grant is inconsistent with the High Court precedent it was bound to follow. ${ }^{50}$

However, as the High Court in NRDC intended to consolidate rather than rewrite the existing law, ${ }^{51}$ a comprehensive exploration of relevant principle requires that regard be had not to NRDC alone. The High Court's NRDC decision has been endorsed, followed and interpreted in a number of Australian cases. Those cases are examined below according to the subject matter categories in which they fall.

\footnotetext{
new law of electric induction'. The applicant indicated that the inventive concept is the 'revelation and utilisation of an antimatter voltage force that stems from the discovery of electrosubtronic fields and culminated in the new science of subtronics'. The Deputy Commissioner held that the invention claimed is a scientific theory or discovery of the laws of science without a specific practical and useful application and that, if a specific application were claimed, such an invention is not fully described.

${ }^{47}$ NRDC (1959) 102 CLR 252, 264.

${ }^{48}$ Ibid 270.

${ }^{49}$ McEniery, 'Patents for Intangible Inventions in Australia after Grant $v$ Commissioner of Patents (Part 1)', above n 15.

${ }^{50}$ McEniery, 'Patents for Intangible Inventions in Australia after Grant $v$ Commissioner of Patents (Part 2)', above n 15. See also McEniery, 'The Patentability of Non-Physical Inventions: Lessons from the United States', above n 2, 384-6.

${ }^{51}$ National Research Development Corporation v Commissioner of Patents (1959) 102 CLR 252, 269.
} 


\section{A Post-NRDC Cases Discussing 'Manner of Manufacture'}

\section{$1 \quad$ Methods of Medical Treatment}

Although the legislation does not expressly exclude methods of medical treatment from patentability, before the decision in Joos $v$ Commissioner of Patents in 1972 ('Joos') ${ }^{52}$ surgical or medical treatment of the human body, as well as non-medical procedures such as cosmetic treatments, were thought to be excluded from patentability. ${ }^{53}$

Joos concerned a cosmetic process of treating human hair and nails. The issue considered by the High Court was whether this process is a patentable 'manner of manufacture' for the purposes of the predecessor to the current legislation, the Patents Act 1952 (Cth). Barwick CJ, sitting alone, regarded the process as patentable, but distinguished it from medical treatment of disease, malfunction or incapacity, which he thought, without deciding the matter, might be 'essentially non-economic' in nature and therefore unsuitable for the grant of patent rights. In contrast his Honour regarded a cosmetic treatment of the human body as being of economic significance. ${ }^{54}$

His Honour considered that the need, as described in $N R D C$, for an invention to be of economic or commercial significance, not to be that a process must have a commercial application. ${ }^{55}$ Instead, his Honour considered that the underlying notion was that the activity must fall within the useful arts, rather than the fine arts. ${ }^{56}$

The conclusion he reached was that the activity of the hairdresser does not fit within the fine arts, but does fit comfortably within the useful arts. ${ }^{57}$ Given

\footnotetext{
52 (1972) 126 CLR 611 (Barwick CJ).

${ }^{53}$ Ibid 619-20. The source of the belief that surgical or medical treatment of the human body are not patentable appears to be $R e C \& W$ 's Application (1914) 31 RPC 235 (SG). See also The Upjohn Company (Robert's) Application [1977] RPC 94.

${ }^{54}$ Ibid 619-23. It would appear that his Honour was influenced by cases such as $\operatorname{Re} C \& W$ 's Application (1914) 31 RPC 235 and Schering AG's Application [1971] RPC 337 in this regard.

${ }^{55}$ Ibid 623-4 citing: National Research Development Corporation $v$ Commissioner of Patents (1959) 102 CLR 252; Re an Application for a Patent by Henry Barnato Rantzen (Rantzen's Application) (1946) 64 RPC 63, 66; Re Lenard's Application (1954) 71 RPC 190, 192.

${ }^{56}$ Ibid 624 citing Re Virginia-Carolina Chemical Corporation's Application (1958) RPC 35, 36.

${ }^{57}$ Ibid 624.
} 
this explanation, it is hard to conceive that his Honour, if the question were put before him in an appropriate case, would find non-cosmetic medical treatment of disease, malfunction or incapacity essentially non-economic. His Honour said:

In this case, the processes are to be used in what cannot be described otherwise than as a commercial activity of hairdressing, a sector of activity which accounts, I imagine, for a great deal of employment. I could not assign the skill of the hairdresser to the area of the fine arts and have little difficulty in placing it in the area of the useful arts. In my opinion, it is an activity in the field of economic endeavour and has commercial significance as those expressions ought to be understood in relation to the grant of patents. ${ }^{58}$

In Anaesthetic Supplies Pty Ltd v Rescare Ltd, ${ }^{59}$ the Full Court of the Federal Court appeared to accept that a device and method for dealing with sleep apnoea was patentable subject matter, although the patent failed on other grounds. Following the first instance decision of Gummow $\mathrm{J},{ }^{60}$ Lockhart and Wilcox JJ by majority rejected the assertion that a method of treating the human body might be 'generally inconvenient'. They held that it is for Parliament, not the courts, to determine whether otherwise patent eligible inventions should be denied protection on matters of ethics and social policy. ${ }^{61}$ Only Sheppard J found to the contrary, holding that granting a patent for a method of medical treatment would be 'generally inconvenient'. His Honour's rationale was that a court should not contemplate granting a patent over a surgical procedure to one medical practitioner if to do so might result in the death or unnecessary suffering of countless people. ${ }^{62}$

The approach to the patentability of methods of medical treatment taken in Anaesthetic Supplies Pty Ltd v Rescare Ltd was affirmed by the Full Court of the Federal Court in Bristol-Myers Squibb Company v F H Faulding \& Co $L t d .{ }^{63}$ This case concerned the validity of two petty patents for methods of administering taxol, a compound originally obtained from the bark of the Pacific yew tree, that has been found to inhibit the growth and division of

\footnotetext{
${ }^{58}$ Ibid.

59 (1994) 50 FCR 1 (Lockhart, Sheppard and Wilcox JJ).

${ }^{60}$ Rescare Ltd v Anaesthetic Supplies Pty Ltd (1992) 25 IPR 119, 151.

${ }^{61}$ Anaesthetic Supplies Pty Limited v Rescare Limited (1994) 50 FCR 1, 16-19 (Lockhart J), 45 (Wilcox J).

${ }^{62}$ Ibid 41.

${ }^{63}$ [2000] FCA 316 (Black CJ, Lehane and Finkelstein JJ).
} 
certain cancer cells. ${ }^{64}$ The claimed methods prescribed the doses of taxol to be administered over certain timeframes. ${ }^{65}$ In cases such as this, it is important to distinguish between a patent for a drug and a patent for a method of administering a drug. Taxol is a naturally occurring compound and thus in itself unpatentable. At the priority date, taxol was a known substance and its great promise as an anti-cancer drug had been known for many years. What was not known were the optimal doses by which the drug should be administered in order to reduce toxicity within the body, which is the problem this invention was designed to overcome. In upholding the patentability of the method, Black CJ and Lehane J pointed out

the insurmountable problem, from a public policy viewpoint, of drawing a logical distinction which would justify allowing patentability for a product for treating the human body, but deny patentability for a method of treatment. ${ }^{66}$

While they mark some progression in the thinking regarding the application of patent law to methods of treating of the human body, none of the cases involving methods of medical treatment makes specific reference to the need to produce a physical effect or cause a physical transformation of matter. Although all methods of medical treatment involve biochemical transformations occurring within the human body, the courts make no mention of this and do not question whether physical changes of this nature are sufficient to invoke patentability. The courts' focus has instead been on the economic or commercial significance of any artificially created state of affairs the methods employ. Given this focus, the cases demonstrate that it is commercial significance, not physicality, that is the essential prerequisite to patent eligibility.

\section{Computer Software}

The next step in the evolution of the patentable subject matter standard was the acceptance of computer software patents as patent eligible subject matter.

Computer software and hardware are inextricably linked. General purpose computers are a generic platform upon which software runs. Once they are running software, general purpose computers behave like specific machines designed to perform the particular function the software is coded to perform.

\footnotetext{
${ }^{64}$ Ibid [1].

${ }^{65}$ Ibid [4].

${ }^{66}$ Ibid [15].
} 
As most general purpose computers are inoperable in the absence of computer software, it is software rather than hardware, that dictates much of the functionality of computers. ${ }^{67}$ Likewise, software without a computer is useless.

General purpose computers are a boon to innovation as they are the foundation upon which new innovative programs can be built. Software is a series of instructions that instruct a computer to perform a particular function. Software allows new information-processing advances to be devised by programmers who, with the help of an operating system, do not need to be concerned with, or even understand, the interaction between software code and the underlying computer hardware. Since general purpose computing machines already exist, programmers no longer need to 'reinvent the wheel', so to speak, by building their own machine. While software designed to run on a computer does need a machine to run, the machine itself forms part of the prior art and predates any inventive advance for which the programmer is responsible. The consequence is that most non-obvious computer software which is designed to run on a computer will not involve an inventive advance that has any significant physical element. This does not change the fact that a piece of software can be as useful and socially beneficial as any machine.

It was initially thought that computer software was not amenable to patent protection because it fell within the prohibition on offering patents for schemes, plans for business, directions for performing a mental act and intellectual information. ${ }^{68}$ However, when this was put to the test, courts

${ }^{67}$ Functionality can of course also be built into hardware. However, the beauty of building functionality at the software level is that software is much easier and less expensive to produce than specifically programmed hardware machines or components.

${ }^{68}$ James Lahore, 'Computers and the Law: The Protection of Intellectual Property' (1978) 9(1) Federal Law Review 15, 22-3. See also British Petroleum Co Ltd's Application (British Petroleum) (1968) 38 AOJP 1020, 1021 (stating that methods of operating a general-purpose computer are inherently unpatentable because they are not a manner of new manufacture. It was also considered public policy that an owner of hardware should be able to use his or her machine freely 'as he thinks fit': 'Computer programming is a relatively young art and, although many stratagems and simplifications have been devised so far, a much greater number may be expected to be devised in the future. It would certainly be mischievous to the State and generally inconvenient if, after investing a million dollars in a computer, the owner were to find himself prevented from operating it efficiently, or in any other manner he may wish, or with any degree of privacy or secrecy he may desire.'); Badger Company Incorporated's Application (Badger) [1970] RPC 36, 40 (PAT) (finding a method of preparing, tabulating and codifying data to be inherently unpatentable because of the conceptual nature of the raw material, and its failure to contribute to the fashioning of a product). 
overcame these difficulties by applying general principles of patent law and found computer software to be patentable subject matter. Australian law fell into step with the position in the United States. ${ }^{69}$ The courts focussed on the application of the program to produce a practical and useful result, rather than treating software as being nothing more than intellectual information. ${ }^{70}$ This approach debunked any suggestion that computer software was a special category of innovation that required special rules.

In two pre-1977 United Kingdom cases it was held that computer programs are a proper subject matter for letters patent when embodied in some physical form.

In Burroughs Corporation (Perkin's) Application, ${ }^{71}$ the question before the Patents Appeal Tribunal was whether a claim to a method of transmitting information between a central master computer and a ring of outlying connected slave computers is a proper subject matter for letters patent. The tribunal held that, as the method involved some alteration in the operability of a physical object, the test set out in NRDC would be satisfied and the method would be patentable. ${ }^{72}$

In relation to the requirement that there be a 'vendible product', Graham $\mathbf{J}$ said:

it is not enough to take a narrow and confined look at the 'product' produced by a method. Of course, if a method is regarded purely as the conception of an idea, it can always be said that the product of such a method is merely intellectual information. If, however, in practice the method results in a new machine or process or an old machine giving a new and improved result, that fact should in our view be regarded as the 'product' or the result of using the method, and cannot be disregarded in considering whether the method is patentable or not. ${ }^{73}$

\footnotetext{
${ }^{69}$ The United States position is described in Diamond $v$ Diehr, 450 US 175 (1981).

${ }^{70}$ CCOM v Jiejing (1994) 122 ALR 417 [128]; Grant [2006] FCAFC 120 (18 July 2006) [29]; Welcome Real-Time SA v Catuity Inc [2001] FCA 445 (17 May 2001) [122], [128]. Unlike in other jurisdictions, such as in Europe, there is no legislative provision in Australia expressly limiting the patentability of computer software. The Patents Act 1990 (Cth) does not define or refer specifically to software.

${ }^{71}$ [1974] RPC 147 (PAT) (Graham and Whitford JJ). Graham J gave an opinion on behalf of the Tribunal.

${ }^{72}$ Ibid 158.

${ }^{73}$ Ibid.
} 
Graham J expressed the view that computer software can be patented and will not be regarded merely as intellectual information to the extent that its claims are directed to an embodiment in some apparatus or process of manufacture.

If the bare method or idea is also clothed by the patentee in his specification with a practical garment in the shape of apparatus enabling that method or idea to be realised in practice, it should no longer be regarded as a naked conception, for it has found a practical embodiment in the apparatus. It is then a manner of new manufacture. ${ }^{74}$

His Honour distinguished Rolls-Royce Limited's Application, which involved no modification of the aircraft itself in order to make it operate more quietly.

In the present case the method necessarily involves a modification. The system is programmed so that it must in every case operate in accordance with the method claimed whenever and by whomsoever it is put into operation. The programme in fact constrains the apparatus to function in a particular way as long as the apparatus embodies that programme. In the Rolls-Royce case on the other hand it can be said that the method was no more than information or instructions which could be given to a pilot on which he might, or might not, act. ${ }^{75}$

Graham $\mathrm{J}$ then went on to draw a connection between computer software and a physical effect when he said, 'computer programs which have the effect of controlling computers to operate in a particular way, where such programs are embodied in physical form, are proper subject matter for letters patent. ${ }^{, 76}$

His Honour considered the mere fact that the computer software would need to be recorded on some physical storage medium, such as magnetic tape (as would have been the readily available technology at the time), or that the software would run on a physical device such as a computer, to be the indicative factors. It was these physical aspects that his Honour relied upon to classify the software as being inherently patentable rather than purely intellectual information. ${ }^{77}$ However, while this statement indicates that his

\footnotetext{
${ }^{74}$ Ibid.

${ }^{75}$ Ibid 160 .

${ }^{76}$ Ibid 161.

${ }^{77}$ Graham J agreed with the contention of Mr Rogers of counsel that Slee \& Harris's Application [1966] RPC 194 was wrongly decided. The claim in Slee \& Harris was for a 'method of operating a computer' that involved an improved technique of 'linear programming' which was refused on the basis that the only 'product' of the method was intellectual information which was not a 'vendible product': ibid 196-7.
} 
Honour considered these physical aspects to be indicative of patent eligibility, it does not necessarily indicate that they are a prerequisite to patent eligibility.

This decision was followed four years later by Graham and Whitford JJ in International Business Machines Corporation's Application (IBM's Application) ${ }^{78}$ the last case relating to computer programs decided in the United Kingdom before the commencement of the 1977 Act. The case involved the automation of a known method of processing financial data in a computer software program. It was held that the method of operating or controlling a conventional computer to process financial data was inherently patentable, as was the computer program by which the method was effected. The software program involved was designed to automatically calculate the selling price of stocks or shares by comparing a list of buy and sell orders.

Despite accepting that the scheme was not itself novel and that a completely standard computer could be programmed to perform it, Graham and Whitford JJ upheld the patent. The argument that a known computer programmed in a new way differed in intellectual content only, and was thus inherently lacking novelty, was expressly rejected. The court held that ' $[t]$ here must be different holes in the card [embodying the program] or different magnetic patterns on the tape, or some other automatic control imposed to ensure that the computer carries out the particular operation required'. ${ }^{79}$ Thus, it was differences in the physical manifestation of data as recorded on physical media that precluded the program and programmed computer from being mere mechanical equivalents to previous programs and computers respectively. ${ }^{80}$

The decisions in these cases have found favour in Australia. Burroughs Corporation (Perkin's) Application was later cited with approval in 1991 by Burchett $\mathrm{J}$ in the Federal Court decision of International Business Machines Corporation $v$ Commissioner of Patents ${ }^{81}$ and both decisions were cited with approval by the Full Court of the Federal Court in 1994 in CCOMv Jiejing. ${ }^{82}$

\footnotetext{
78 [1980] FSR 564 (PAT) (Graham and Whitford JJ).

${ }^{79}$ Ibid 569.

80 Justine Pila, 'Inherent Patentability in Anglo-Australian Law: A History' (2003) 14 Australian Intellectual Property Journal 109, 159. See also Slee and Harris's Application [1966] RPC 194; Gever's Application [1970] RPC 91; and Badger Co Inc's Application [1970] RPC 36.

${ }^{81}$ (1991) 22 IPR 417. This case is sometimes also cited as International Business Machines Corporation v Smith, Commissioner of Patents.

${ }^{82}$ (1994) 122 ALR 417.
} 
In one of the earlier Australian cases involving computer software, International Business Machines Corporation v Commissioner of Patents, Burchett $\mathrm{J}$ held that software inventions are potentially patentable subject matter, given the expansive approach taken in NRDC. The invention in question concerned an improved 'method and apparatus for generating curves on computer graphics displays ${ }^{83}$ It was objected to on the grounds that it recites, and wholly pre-empts, a mathematical algorithm. The word, 'algorithm' was defined by the court to mean, 'a procedure for solving a given type of mathematical problem' ${ }^{84}$

Burchett $\mathrm{J}$ drew the same distinction between a mere algorithm and a useful commercial application of the algorithm as had been drawn in the United States, and held that the software in dispute was the latter ${ }^{85}$ His Honour held that, while the mathematics of the invention were not new, the application to computers to produce an improved curve was a new and commercially useful result in the field of computer graphics, and the invention was patentable. ${ }^{86}$

\begin{abstract}
Just as those compounds were previously known, so here, it is not suggested there is anything new about the mathematics of the invention. What is new is the application of the selected mathematical methods to computers, and in particular, to the production of the desired curve by computer. This is said to involve steps which are foreign to the normal use of computers and, for that reason, to be inventive. The production of an improved curve image is a commercially useful effect in computer graphics. ${ }^{87}$
\end{abstract}

With regard to physical effect or transformation, Burchett $\mathrm{J}$ only held that the method of producing an improved curved image on a computer would be patentable because it creates a 'commercially useful effect' ${ }^{88} \mathrm{He}$ did not say that the invention in question was patentable because it involved a physical aspect, such as a computer or a storage device, although he may have thought it unnecessary to do so given that he cited Burroughs Corporation (Perkin's) Application favourably. On the other hand, it could be that his Honour chose

${ }^{83}$ International Business Machines Corporation v Commissioner of Patents (1992) 22 IPR 417, 418.

${ }^{84}$ Ibid 419.

${ }^{85}$ Ibid 419-20 citing with approval Gottschalk v Benson, 409 US 63, 67 (1972) and Parker v Flook, 198 USPQ 193, 199 (1978). Burchett J did not expressly endorse, reject or apply the United States Federal Circuit's Freeman-Walter-Abele formula. However, he noted that he did not believe that the United States case law was inconsistent with his view.

${ }^{86}$ Ibid 424-5.

${ }^{87}$ Ibid 424.

${ }^{88}$ Ibid. 
to disregard this aspect of those decisions without drawing attention to the fact he had done so. It would appear unlikely that Burchett $J$ would have been in favour of a physicality requirement, as his Honour preferred the view that it is by 'the production of some useful effect that patent law has distinguished ... between the discovery of a principle of science and the making of an invention'. ${ }^{89}$ Consequently, it can be assumed that where a commercially useful effect can be discerned from the terms of the claim, the claim concerns an invention as opposed to a principle of science or law of nature, and is therefore inherently patentable subject matter, regardless of any physical basis to the claim. ${ }^{90}$

The Full Court of the Federal Court in CCOM v Jiejing ${ }^{91}$ affirmed Burchett J's decision in International Business Machines Corporation v Commissioner of Patents. In CCOMv Jiejing, the Full Court considered the patentability of a Chinese language word processor. The invention was a computer software apparatus used to assemble and record text in Chinese characters. It consisted of software running on a conventional computer with a standard keyboard and monitor specially adapted to facilitate input of Chinese characters from a database. $^{92}$

In a unanimous decision, the Full Court found the invention to be patentable subject matter. In doing so, the Court explained that the patentable subject matter formulation in $N R D C$ could be applied to computer software inventions.

The NRDC Case (102 CLR at 275-277) requires a mode or manner of achieving an end result which is an artificially created state of affairs of utility in the field of economic endeavour. In the present case, a relevant field of economic endeavour is the use of word processing to assemble text in Chinese language characters. The end result achieved is the retrieval of graphic representations of desired characters, for assembly of text. The mode or manner of obtaining this, which provides particular utility in achieving the end result, is the storage of data as to Chinese characters analysed by stroke-type categories, for search including 'flagging' (and 'unflagging') and selection by reference thereto. ${ }^{93}$

\footnotetext{
${ }^{89}$ Ibid 423.

${ }^{90}$ Andrew Christie and Serena Syme, 'Patents for Algorithms in Australia' (1998) 20(4) Sydney Law Review 517.

${ }^{91}$ (1994) 122 ALR 417 (Spender, Gummow and Heerey JJ).

${ }^{92}$ Australian Petty Patent No 616, 154 ('Symbol Definition Apparatus').

${ }^{93}$ CCOMv Jiejing (1994) 122 ALR 417, 450.
} 
The court addressed the relationship between patentable inventions and physical form when discussing the concept of manufacture. In relation to the invention in $N R D C$, the Full Court said that the 'central question in the case' was:

whether a process for killing weeds could be within the relevant concept of invention in $\mathrm{s} 6$ because it produced a useful physical result in relation to a material or tangible entity. ${ }^{94}$

Read alone, this statement does not make clear whether the Full Court was reading a physicality requirement into the $N R D C$ test, or whether it considered the presence of a physical aspect only to be an indication or 'clue' that a method involving the use of an algorithm is patentable, as opposed to being a mere abstract idea. At no point in the judgment does the court specifically state that producing a physical effect or causing a physical transformation of matter is a required element of patent eligibility. ${ }^{95}$

It is, however, made clear by the cases involving computer software inventions cited by the Full Court in the course of its reasons that it is the second of these that is supported. ${ }^{96}$ That is, the court regarded physicality as merely a clue that indicates patentability. The court noted that in the last case relating to computer programs decided in the United Kingdom before the commencement of the 1977 Act, International Business Machines Corporation's Application, ${ }^{97}$ Graham and Whitford JJ, sitting as the Patents Appeal Tribunal, held that a claim to software designed to automatically calculate the selling price of stock or shares in an auction market involved more than just 'intellectual information' because the method was involved in the program and in the apparatus in physical form..$^{98}$ There was nothing in that case that indicated that the judges saw this physical form as a prerequisite to patentability.

\footnotetext{
${ }^{94}$ Ibid 446 citing NRDC (1959) 102 CLR 252, 268.

${ }^{95}$ In particular see the court's application of the law to the facts: CCOM v Jiejing (1994) 122 ALR 417, 450.

${ }^{96}$ Burroughs Corporation (Perkin's) Application [1974] RPC 147; CCOM v Jiejing (1994) 122 ALR 417, 446, 448-449; International Business Machines Corporation's Application (1980) FSR 564; International Business Machines Corporation v Commissioner of Patents (1991) 33 FCR 218.

${ }^{97}$ [1980] FSR 564.

98 CCOM v Jiejing (1994) 122 ALR 417, 448 citing International Business Machines Corporation's Application (IBM's Application) [1980] FSR 564, 572.
} 
The court also noted the earlier Federal Court decision of International Business Machines Corp v Commissioner of Patents, ${ }^{99}$ in which Burchett $\mathbf{J}$ followed the decision of the Patents Appeal Tribunal in Burroughs Corporation (Perkin's) Application, where the same two judges, Graham and Whitford JJ, expressed the view that computer programs embodied in physical form are proper subject matter for letters patent. ${ }^{100}$ The judges expressed the view that a computer software invention can be patented, and will not be regarded as merely intellectual information, to the extent that it claims an embodiment in some apparatus or process of manufacture. ${ }^{101}$

CCOM v Jiejing firmly established in Australia that computer software is something more than an unpatentable mathematical algorithm or a mere abstract idea. Following CCOM $v$ Jiejing, it would seem that the mere presence of a physical device associated with a computer program will be enough to ensure it will not be rejected for being an unpatentable mathematical algorithm or a mere abstract idea, provided that the combination of the device and software satisfies the $N R D C$ requirement that a method be a manner of achieving an artificially created state of affairs that is of practical utility in the field of economic endeavour. ${ }^{102}$ However, there is nothing in the decision to suggest that physicality is a perquisite to patentability. Given that the technology is such that most computer software runs on general purpose computers, it seems at first glance that a lack of physical effect is not likely to be a successful argument against patenting computer software. While the High Court has not directly addressed the patent eligibility of computer software, it made comments by way of obiter in Data Access Corporation $v$ Powerflex Services Pty $L t d,{ }^{103}$ which indicate that it approved of the approach taken by the court in CCOM v Jiejing. There the Court, citing CCOM v Jiejing in a footnote, said:

In Australia claims to computer programs which are novel, not obvious and otherwise satisfy the Patents Act 1990 (Cth) and which have the effect of controlling computers to operate in a particular way, have been held to be proper subject matter for letters patent, as 'achieving an end result which is an artificially created state of affairs of utility in the field of economic

\footnotetext{
${ }^{99}$ (1991) 33 FCR 218; 105 ALR 388.

${ }^{100}$ CCOM v Jiejing (1994) 122 ALR 417, 448-9 citing Burroughs Corp (Perkin's) Application [1974] RPC 147, 161.

${ }^{101}$ Burroughs Corporation (Perkin's) Application [1974] RPC 147, 158.

${ }^{102}$ Anne Fitzgerald and Scott Phillips, 'Patentability of Software in Australia: CCOM v Jiejing' (1994) 5(2) Journal of Law, Information and Science 296, 304-5.

103 (1999) 202 CLR 1 (Gleeson CJ, Gaudron, McHugh, Gummow and Hayne JJ).
} 
endeavour', within the meaning of National Research Development Corporation $v$ Commissioner of Patents. ${ }^{104}$

The view that software is patentable simply because it affects the operation of an apparatus in a physical form was adopted (by way of obiter) by the Full Federal Court in Grant. The Court in Grant regarded the physicality requirement as having been met in respect of claims to computer software where the software affects the operation of an apparatus in a physical form (which would include a computer). The Court took the view that a change in state or information in a machine, or part of a machine, is a physical effect of the requisite kind. The Court said:

In Catuity and CCOM as in State Street and $A T \& T$, there was a component that was physically affected or a change in state or information in a part of a machine. These can all be regarded as physical effects. ${ }^{105}$

With respect, the views of Burchett $\mathrm{J}$ in International Business Machines Corp v Commissioner of Patents, Graham and Whitford JJ in Burroughs Corporation (Perkin's) Application and International Business Machines Corporation's Application and the Full Federal Court in Grant are problematic. The view taken by these judges is that computer software is certainly patent eligible because the general purpose computers it runs, and the media the programs are recorded on, are physical objects. ${ }^{106}$ This ignores the fact that computers and data storage devices are not a part of the inventive concept of software, but are the base or foundation upon which the inventive concept is built.

The problem with this logic is that the physical aspect is not embedded in the algorithm as such, but rather exists in the computer upon which the software runs. The approach fails to consider the argument that software is an intangible product. It is true that software requires a physical device such as a general purpose computer to run or a storage medium upon which it is recorded. However, to think that software running on a general purpose computer might be unpatentable because it does not involve a physical effect or transformation is to confuse an incidental physical medium with the

\footnotetext{
${ }^{104}$ Ibid 15 citing CCOM Pty Ltd v Jiejing Pty Ltd (1994) 51 FCR 260, 295.

${ }^{105}$ Grant [2006] FCAFC 120 (18 July 2006) [32].

${ }^{106}$ It should be noted that Burchett, Graham and Whitford JJ in these instances appear not to take the view that the physical relationship between particular software and any computer upon which it runs is a basis for finding that patentable subject matter exists.
} 
inventive breakthrough. ${ }^{107}$ The fallacy inherent in this argument becomes obvious when the principle of hardware/software equivalence is considered. That principle is that anything implemented in software can be replicated in hardware to achieve the same result. The benefit of building functionality into software is that software is easier and less expensive to produce than a specifically programmed machine. Since a machine programmed to perform a specific task is undoubtedly patentable subject matter, there is no reason why functionally equivalent software should be treated differently. ${ }^{108}$ For these reasons, patent drafting that seeks to show a physical interaction between software and an underlying computer promotes form over substance. ${ }^{109}$ According to Durham:

Such things should be considered to be at the core of patentable subject matter, without straining to rely on the tangible aspects of the computer hardware. The silicon and wire of the computer circuits, the electrons that course through those circuits, the mouse and keyboard that provide input, and the monitor or paper that displays the results are all physical entities. ${ }^{110}$

Further, the physical hardware platform forms part of the prior art and is therefore not in substance part of any software invention.

For this reason, any finding that Australian law contains a physicality requirement would necessitate a reconsideration of whether computer software is patentable, or an explanation of how software running on a general purpose computer could possibly satisfy the physicality requirement. This is the case since computer software, running on a known general purpose

${ }^{107}$ Ben McEniery, 'Physicality in the Information Age: A Normative Perspective on the Patent Eligibility of Non-Physical Methods' (2011) 10 Chicago-Kent Journal of Intellectual Property 106, 191-2.

108 Dennis S Karjala, 'Distinguishing Patent and Copyright Subject Matter' (2003) 35 Connecticut Law Review 439, 444-5; Brian Fitzgerald et al, Internet and E-commerce Law: Technology, Law and Policy (Thomson Reuters, 2007) 299.

109 That being said, it may still be prudent for patent attorneys to draft patent applications claiming computer software in a way that makes specific reference to physical objects, such as input devices for receiving data, interactions with the computer's memory for storing data, interactions with the computer's processor, and an output mechanism for displaying data to a human (or another machine), for the reason that the courts and patent offices are still susceptible to granting patents where a physical element is disclosed, even though the hardware often has little or no connection to the inventive breakthrough. Cohen and Lemley call this 'the doctrine of the magic words': Julie E Cohen and Mark A Lemley, 'Patent Scope and Innovation in the Software Industry' (2001) 89 California Law Review 1, 9.

${ }^{110}$ Alan Durham, 'Useful Arts in the Information Age' (1999) Brigham Young University Law Review 1419, 1514. 
computer, does not ordinarily produce or physically transform a tangible article, but merely manipulates or outputs data. Rather, the recognition that computer software is patentable demonstrates that a physicality requirement is not an essential part of the patentable subject matter test. The better view, therefore, is that taken by Federal Court in CCOM v Jiejing, which involves an investigation as to whether the manner of obtaining the end result achieved is a manner of manufacture, irrespective of whether invoking the claimed method results in a transformation of physical matter.

\section{Business Methods}

While it is now clear that business methods, as a class, are not automatically excluded from patentability, ${ }^{111}$ following Grant, it can only really be said with certainty that a business method will fall safely within the scope of patentable subject matter if it operates sufficiently upon, or in relation to, some tangible physical item or device. ${ }^{112}$

For a time, the prevailing assumption in Australia had been that business methods were excluded from patentability as a class of invention. ${ }^{113}$ In Quigley Co Inc's Application, ${ }^{114}$ the Assistant Commissioner of Patents was asked to consider the patentability of a method of increasing steel production

\footnotetext{
${ }^{111}$ The business method exception to patentability was rejected in the United States in State Street Bank \& Trust Co. v Signature Financial Group, Inc., 149 F 3d 1368, 1375 (Fed Cir 1998) ('We take this opportunity to lay this ill-conceived exception to rest.') aff'd in $A T \& T$ Corp v Excel Communications, Inc, 172 F 3d 1352 (Fed Cir 1999) and In re Bilski, $545 \mathrm{~F}$ 3d 943, 960 (Fed Cir 2008) (en banc). The State Street rejection of the business method exception was followed by the Federal Court of Australia in Welcome Real-Time SA v Catuity Inc [2001] FCA 445 (17 May 2001) [125]-[126] (Heerey J) and Grant [2006] FCAFC 120 [26]. The patentability of business methods should not have been perceived to be as much of a mystery as one might have thought, given that the modern decisions refuting the business method exception were pre-empted by Re Cooper's Application (1901) 19 RPC 53, 54, and by Re Fishburn's Application (1938) 57 RPC 245, 248, where Morton J said that while a mere scheme or plan is not the proper subject of a patent, an alleged invention which serves a mechanical purpose that has useful results does not become an unpatentable scheme or plan merely because the purpose is in the carrying on of a branch of business.

${ }^{112}$ Grant [2006] FCAFC 120 (18 July 2006).

${ }^{113}$ James Lahore, 'Computers and the Law: The Protection of Intellectual Property' (1978) 9(1) Federal Law Review 15, 22-3 ('Some matter has never been considered to constitute a patentable invention. This matter includes a method of calculation or a process of mathematical operations [including ways of solving mathematical problems], business, commercial and financial schemes, schemes of operation, and printed sheets, cards, tickets or the like which are mere records of intelligence.'); Sam Ricketson, 'Business Method Patents - A Matter of Convenience?' (2003) Intellectual Property Quarterly 97, 109-11.

114 [1977] FSR 373.
} 
by operating two or more furnaces in accordance with a roster to make more effective use of workers. Neither the steel making process itself, nor the operation of a furnace throughout a steel producing period, was new. The steel produced was not improved or modified in any way.

The Assistant Commissioner rejected the submission that this method satisfied the expansive criteria laid down in $N R D C$ and thus constituted patentable subject matter.

I find nothing in those decisions which suggest that such a commonplace management technique as scheduling for the better utilisation of manpower is proper subject matter of a patent. [The applicant] argued that, as more steel is produced in a given period, the method is of economic importance. However, the greater steel output is not due to any change in the method of producing steel or in the way a furnace is operated. It results from the fact that, by operating his directions, the crew is employed more effectively and performs more work in that period. ${ }^{115}$

The Assistant Commissioner took the view that nothing in the NRDC case suggests that a management technique for the better utilisation of manpower is a proper subject matter for a patent, despite the fact that the crew was more effectively employed and use of the method resulted in greater steel output.

He has merely devised a roster or schedule for his work force so as to obtain more work from a normal crew in a given period. He realised that all of the men in a normal crew were not fully employed throughout the duration of a steel producing period. He decided to take up some of the slack by partly overlapping the steel producing periods of two furnaces during that part of the campaign when both are operating at less than the maximum number of steel producing heats per day. It is true that this more effective direction of his work force enables him to obtain more steel producing heats, and thereby produce more steel, in a given period. But that does not alter the fact that all he has done is to devise a roster or schedule to direct the activities of his men in carrying out the various known procedures in the known process of making steel. ${ }^{116}$

According to Ricketson, similar results are to be observed in a number of other pre-NRDC Australian cases. ${ }^{117}$ However, it is difficult to see how such a

\footnotetext{
${ }^{115}$ Ibid.

${ }^{116}$ Ibid.

117 Ricketson, 'Business Method Patents: A Matter of Convenience?', above n 113, 109-10 citing the following: Re Brown (1899) 5 ALR 81 (Supreme Court of Victoria) (an improved method of preventing the fraudulent re-use of sales book dockets); Commissioner of Patents $v$
} 
view is consistent with the principles laid down in $N R D C$, given that the method that was sought to be protected is a process involving the practical operation of an inventive concept to produce an improved result and that is of utility and economic significance.

The notion that Australian law might contain a business method exception was rejected in Australia in Welcome Real-Time SA v Catuity Inc. ('Welcome Real-Time $v$ Catuity'). ${ }^{118}$ The invention considered in Welcome Real-Time $v$ Catuity is a method and device for the operation of smart cards in connection with traders' loyalty programs. The smart cards in question contain microprocessors or chips able to receive and store information. The problem to be overcome was that the smart cards have only 'a small memory capacity', which, when using conventional 'static' methods to store information, can only store loyalty points information in relation to a limited number of traders, being fewer than the number of traders who use loyalty programs. The invention overcame this problem by using a dynamic memory allocation technique so the cards could be used across thousands of merchants, each operating their own proprietary loyalty programs. One of the advantages of the dynamic memory allocation technique used was that a portion of memory on a card was only allocated to a trader once a consumer carrying the card actually used that trader's services. ${ }^{119}$

Heerey J, sitting as a single judge in the Federal Court, upheld the patentability of this invention after applying the manner of manufacture test set out in NRDC. In doing so, his Honour distinguished between an unpatentable abstract idea and an idea reduced to a specific practical application in a manner consistent with the approach taken in CCOM $v$ Jiejing.

In my opinion the Patent does produce an artificial state of affairs in that cards can be issued making available to consumers many different loyalty programs of different traders as well as different programs offered by the same trader. All this can be done instantaneously at each retail outlet. So what is involved here is not just an abstract idea or method of calculation. Moreover this result is beneficial in a field of economic endeavour - namely

\footnotetext{
Lee (1913) 16 CLR 138 (an improved method for charcoal burning, consisting of no more than directions for use of existing burners); Neilson v Minister of Public Works (NSW) (1914) 18 CLR 423 (an improved method for utilising an existing mechanism of septic tank purification); Rogers $v$ Commissioner of Patents (1910) 10 CLR 701 (a method of felling trees by use of fire).

118 [2001] FCA 445 (17 May 2001) (Heerey J).

${ }^{119}$ Ibid [18].
} 
retail trading - because it enables many traders (including small traders) to use loyalty programs and thereby compete more effectively for business. ${ }^{120}$

In doing so, he recognised that the invention before the court involved both a method and a device, and as such was not a pure, or non-physical, business method.

What is disclosed by the Patent is not a business method, in the sense of a particular method or scheme for carrying on a business ... Rather, the Patent is for a method and a device, involving components such as smart cards and POS terminals, in a business; and not just one business but an infinite range of retail businesses. ${ }^{121}$

In assessing the patent eligibility of this invention, Heerey $\mathrm{J}$ made clear that, as in the United States, there is no business method exception to patentability in Australia. His Honour found the US Federal Circuit's State Street Bank \& Trust Co v Signature Financial Group ('State Street') ${ }^{122}$ decision persuasive, despite the United States test for patentable subject matter being different to that in Australia, and the United States patent law having a different historical source owing little or nothing to the Statute of Monopolies. ${ }^{123}$ The reasons his Honour gave to support this finding were that:

the social needs the law has to serve in that country are the same as in ours. In both countries, in similar commercial and technological environments, the law has to strike a balance between, on the one hand, the encouragement of true innovation by the grant of monopoly and, on the other, freedom of competition. $^{124}$

\footnotetext{
${ }^{120}$ Ibid [127].

${ }^{121}$ Ibid [128] (original emphasis).

122 State Street Bank \& Trust Co. v Signature Financial Group, Inc., 149 F 3d 1368 (Fed Cir 1998), cert denied 525 US 1093 (1999). According to the Federal Circuit in State Street, an invention will be patentable subject matter if it 'produces a useful, concrete and tangible result', a test the meaning of which the court never explained. The test has since been abandoned, having been described by the Federal Circuit as being 'insufficient to determine whether a claim is patent-eligible': In re Bilski, 545 F 3d 943, 959 (Fed Cir 2008). The Federal Circuit's view was endorsed by the Supreme Court on appeal: Bilski v Kappos, 561 US (2010). For a critique of the Federal Circuit's now overruled decision in In re Bilski, 545 F 3d 943, 959 (Fed Cir 2008), see Benjamin J McEniery, 'The Federal Circuit in Bilski: The Machine-or-Transformation Test' (2009) 91(4) Journal of the Patent and Trademark Office Society 254.

${ }^{123}$ Welcome Real-Time SA v Catuity Inc [2001] FCA 445 (17 May 2001) [129].

${ }^{124}$ Ibid.
} 
In relation to the physicality issue, Heerey $\mathrm{J}$ noted that the High Court in $N R D C$ had not determined the issue of whether an invention requires a physical effect or transformation of matter to be patentable. ${ }^{125}$ Therefore, his Honour did not regard the law as requiring a physically observable effect. He also noted that he did not need to decide the issue in any event, since the invention before him did involve a physically observable effect.

The respondents' argument for distinguishing CCOM - the supposed lack of 'physically observable effect' — turns on an expression not found in CCOM itself. Nor does such a concept form part of the Full Court's reasoning. In any event, to the extent that 'physically observable effect' is required (and I do not accept that this is necessarily so) it is to be found in the writing of new information to the Behaviour file and the printing of the coupon. ${ }^{126}$

The invention claimed in Welcome Real-Time $v$ Catuity does not involve the creation of a machine or other physical device. Instead, it is a means of recording data on an existing physical device. It arguably involves a transformation of matter. After a smart card is used in accordance with the claimed method, the state of the magnetic strip that houses the data is altered to the extent that electrons that comprise the strip are re-arranged to record the data stored on the card. This is not an incidental physical transformation. It is integral to the dynamic data storage method claimed.

In Welcome Real-Time $v$ Catuity and CCOM $v$ Jiejing the patentable inventions were commercially useful methods of manipulating data and information. In both cases, the reduction of the methods to electronic devices had replaced what had previously been a laborious exercise in manual and mental administration: collecting a prescribed number of stamps that were then sent to a central location and a gift sent in return in Welcome Real-Time $v$ Catuity; and translation from one language into another in CCOM v Jiejing. It is this automation that gives the inventions practical utility and economic significance. This suggests that automated methods are patentable subject matter, provided they are sufficiently described and capable of exact, or substantially identical, repetition.

\footnotetext{
${ }^{125}$ Ibid [113].

${ }^{126}$ Ibid [128].
} 


\section{Conclusion}

The argument made in this article is that the post-NRDC, pre-Grant cases do not support a physicality requirement. Instead, they support a broad, flexible and technology-neutral approach to the patentable subject matter inquiry devoid of physical constraints. This article disputes the validity of the assertion made in the Federal Court's decision in Grant that the physicality requirement established is consistent with the existing case law. The cases examined show that it is economic and commercial significance, rather than physical embodiment, that is the focus of the patentable subject matter inquiry. Accordingly, the argument made is that, by finding in favour of a physicality requirement, the Federal Court's decision in Grant is not consistent with $N R D C$ or the post- $N R D C$ case law that preceded it.

The cases examined show that there is a dearth of cases, with the exception of cases involving claims to computer software, in which the patent eligibility of non-physical methods is considered. For this reason, the law surrounding the patent eligibility of non-physical methods is largely to be determined by reference to the law that governs patents for inventions that do involve a physical effect or transformation of matter. Why there is no body of AngloAustralian case law dealing with non-physical inventions or a demonstrable history of patents being granted in respect of them is a matter of conjecture. It is clearly not the case that the invention of new and useful non-physical methods is a recent phenomenon. New and inventive financial transactions, tax minimisation strategies, asset protection schemes, methods of organising a workforce, methods of teaching or training people and animals, compliance procedures and risk-hedging strategies have been used for centuries. So, why is it that their patent eligibility has only recently come to the fore?

It would appear that people either largely presumed that non-physical inventions are not patent eligible, or had not thought to patent innovation of this kind. Such an outcome would be unsurprising given that these are things that fall outside the traditional expectations as to what subject matter the patent system is designed to protect. It may be that our understanding of technology, or our understanding of the purpose and scope of the patent system, has prevented people from seeking patents over non-physical inventions. It cannot merely be assumed that, since there has not been a consistent practice of patents for non-physical inventions being sought or granted, these things are not patentable.

Despite there being cases in which the patent eligibility of methods of medical treatment involving biochemical transformations occurring within the human body has been considered, in none of these cases has a physicality 
requirement been expressly considered or invoked. ${ }^{127}$ The courts' focus has instead been on the economic or commercial significance of any artificially created state of affairs the methods produce. Given this focus, the cases demonstrate that it is commercial significance, not physicality or moral acceptability, that is the essential prerequisite to patent eligibility.

Likewise, the computer software cases do not support a physicality requirement. ${ }^{128}$ Instead, these cases suggest that physicality is only a 'clue' to patentability, not a prerequisite. The focus of those cases has largely been on the practical outcomes that software programs achieve. On a very broad view, it could be said that computer software as we know it today always involves a physical effect because software needs to be recorded on some sort of physical medium and run on a computer (which is a physical device that experiences a change in state as a consequence). This is the view taken in Grant. The better view is that software is an intangible set of instructions that produces a useful informational result, and that any physical change that takes place within a computer running the software is incidental and irrelevant to patentability. Taking this view would lead to the conclusion that a physicality requirement would invalidate most computer software patents. Such a view would be clearly inconsistent with the existing Anglo-Australian case law confirming the patentability of software. For this reason, the courts' recognition that software is patentable subject matter is inconsistent with the existence of a physicality requirement.

Following the software cases is the decision of a single judge of the Federal Court, Heerey J, in Welcome Real-Time v Catuity. Heerey J repeated the fact that the High Court in NRDC had not determined the issue of whether an invention must produce a physical effect or cause a physical transformation of matter and expressed doubt that such a requirement exists. He expressed the view that he himself did not believe that such a requirement exists at law. ${ }^{129}$

The eminent judges in NRDC were very much concerned that the manner of manufacture inquiry be construed so as to allow the patent system to reward,

127 Joos v Commissioner of Patents (1972) 126 CLR 611; Anaesthetic Supplies Pty Ltd v Rescare Ltd (1994) 122 ALR 141.

128 Burroughs Corporation (Perkin's) Application (PAT) [1974] RPC 147; International Business Machines Corporation's Application (IBM's Application) (1980) FSR 564 (PAT); International Business Machines Corporation v Commissioner of Patents (1991) 33 FCR 218 (Burchett J); and CCOM v Jiejing (1994) 122 ALR 417.

129 Welcome Real-Time SA v Catuity Inc [2001] FCA 445 (17 May 2001) [113], [128]. Interestingly, Heerey J's view had changed by the time he sat as a member of the Full Court that decided Grant [2006] FCAFC 120 (18 July 2006). 
and thereby encourage, all new and exciting technological advances. It is argued that this rationale was not the underlying basis of the Federal Court's decision in Grant, which instead sought to find in $N R D C$ and the associated case law a principle to justify curbing the expansion of the scope of patentable subject matter.

The NRDC approach to the patentable subject matter test requires that an artificially created state of affairs that is of economic or commercial significance be created. Thus, to be patent eligible, it is sufficient that an invention involves a specific practical application of an idea or principle to achieve a useful result, and there is no requirement that an invention must produce a physical effect or cause a physical transformation of matter. Rather, a physical effect or transformation is merely an indication, or 'clue', that the subject matter is patent eligible, not a prerequisite. ${ }^{130}$ Accordingly, it is not only traditionally recognised mechanical, industrial, chemical and manufacturing processes that are patent eligible, as patent eligibility extends to include non-physical inventions. The consequence is that the rewards of the patent system will continue to encourage new and innovative technologies, even those knowledge- and information-based inventions that will be the hallmark of the knowledge economy of the Information Age.

It is foreseeable that much of the groundbreaking innovation we are likely to witness in the 'knowledge economy' will involve the use and manipulation of information and data rather than the use and manipulation of physical matter. ${ }^{131}$ Given that the importance of enhancing productivity and profitability through the use of new and innovative methods of processing data and information has come to the fore in recent times, it is of little surprise that people would seek patents for non-physical methods. Whether Australian patent law will keep pace with this reality is as yet unknown. That people would assume that the reach of patent law is limited to new machines, devices and physically-transformative methods is unsurprising given that innovation in bygone eras has been marked by technological advances of this kind. However, this is merely a reflection of the kinds of advances that have

\footnotetext{
${ }^{130}$ This is consistent with the United States Supreme Court's view of United States law: Bilski $v$ Kappos, 561 US _ (2010). Following the recent United States Supreme Court decision in Bilski v Kappos, there is little doubt that no such requirement exists as part of United States patent law: McEniery, 'Physicality in the Information Age, above n 107.

131 John Maddox, What Remains to Be Discovered: Mapping the Secrets of the Universe, the Origins of Life, and the Future of the Human Race (The Free Press, 1998) 375-6; James Canton, The Extreme Future: The Top Trends That Will Reshape the World in the Next 20 Years (Dutton, 2006) 75-8; Richard Watson, Future Files: A History of the Next 50 Years (Scribe Publications, 2007).
} 
previously dominated the technological landscape and hitherto held views about the nature of technology and patent eligibility. It does not necessarily reflect the state of the law or the nature of technology. 